\title{
Pakistan eyes water treaty as Afghanistan plans to step water management
}

By Khaama Press - Wed Sep o6 2017, 2:35 pm

The Pakistan government is looking to sign a treaty with Afghanistan amid ongoing efforts by the Afghan government to boost the management of the waters, it has been reported.

The Climate Change Ministry of

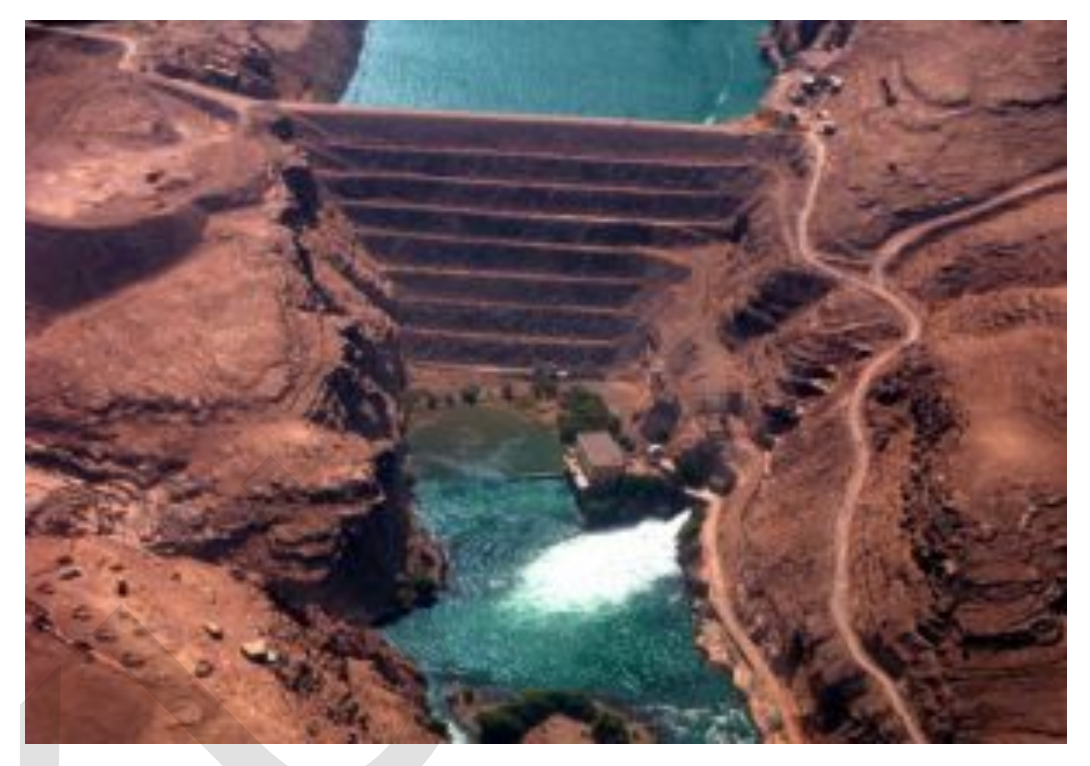

Pakistan has prepared a document based on which the country is seeking ways and possibilities to conclude a treaty with the Afghan government.

According to the local media reports citing the contents of the document, the Pakistani government has a plan to safeguard Pakistan's rights on trans-boundary water inflows according to international norms and conventions.

The reports also indicate that the government of Pakistan has started to explore the possibility of entering into a water treaty with Afghanistan to promote integrated watershed management including ecological conservation practices in uphill watersheds.

This comes as President Mohammad Ashraf Ghani last month said more water dams will be built in western Herat and other provinces of Afghanistan as he unveiled the government's new economic perspectives.

Earlier, President Ghani had said the government is committed for the administration of the waters despite the objections as he called on the youths of the country to step up efforts to eradicate poverty, discrimination, and violence in the country. 
Follow Khaama Press (KP) | Afghan News Agency on Twitter, become a fan on Facebook. Stay updated via $\underline{\text { RSS }}$ 